\title{
Calcification of subcutaneously implanted collagens in relation to cytotoxicity, cellular interactions and crosslinking
}

\author{
M.J.A. VAN LUYN, P.B. VAN WACHEM \\ Department of Cell Biology and Electronmicroscopy, University of Groningen, Oostersingel \\ 69/2, 9713 EZ Groningen, The Netherlands \\ P.J. DIJKSTRA, L.H.H. OLDE DAMINK, J. FEIJEN \\ Department of Chemical Technology, Twente University, p.o. Box 217, 7500 AE Enschede, \\ The Netherlands
}

\begin{abstract}
In general, calcification of biomaterials occurs through an interaction of host and implanted material factors, but up to now the real origin of pathologic calcification is unknown. In this study we aimed to investigate incidence of calcification of (crosslinked) dermal sheep collagens (DSCs) with respect to their specific properties, during subcutaneous implantation in rats. Three types of DSCs were commercially obtained: non-crosslinked DSC (NDSC), and DSC crosslinked with glutaraldehyde (GDSC) and hexamethylenediisocyanate (HDSC).

NDSC, HDSC and GDSC were (enzymatically) tissue culture pretreated to eliminate their cytotoxic products. Beside this, crosslinking methods were modified to optimize mechanical properties and to decrease cytotoxicity, which resulted in HDSC* and GDSC*. Furthermore, DSC was crosslinked by activation of the carboxylic groups, i.e. by means of acyl azide and carbodiimide, resulting in AaDSC and CDSC, respectively. After implantation of HDSCs and GDSCs a relation between cytotoxicity and calcification of crosslinked DSC could be made. No relation was found between cellular infiltration of DSCs and calcification. However, from the use of different types and modification of crosslinking methods it might be concluded that calcification is mainly related to stable crosslinks, i.e. to the chemical properties of the obtained material.
\end{abstract}

\section{Introduction}

Crosslinked collagen or tissue-derived biomaterials rich in collagen are widely used for clinical applications. However, calcification, resulting in degeneration of these materials, is a major disadvantage in applications such as bioprosthetic heart valves [1-7].

$\mathrm{Up}$ to now the origin of collagen calcification is not well understood. Several factors can be involved in this process, such as the type of biomaterial (e.g. degree of crosslinking, positive and negative charged amino acids), host cellular materials and application sites.

To inhibit calcification, treatment of glutaraldehyde (GA) crosslinked collagens with, for example, pro-. tamine sulphate $[8,9]$, by controlled release of diphosphonates [10-13], or L-glutamine acid treatment [14] in order to block residual aldehyde groups, have been studied. Furthermore, pretreatment with epoxy compounds [15], which can both link amino- and carboxylgroups, was performed before GA crosslinking. With all models at least some reduction in calcification was observed.

Thus far only three groups studied the use of different crosslinking, i.e. by use of acyl azide, or by use of cyanamide [16-18], to prevent calcification of the material. The latter is lcss attractive becausc it has limited crosslinking ability and seemed to be effective only in combination with iron (III) citrate [16].

Our group has studied collagen from a different viewpoint. Both in vitro [19-22] and in vivo [23-26] studies were performed with dermal sheep collagens (DSC). Optimization or development of new crosslinking methods was first aimed at preventing cytotoxic effects and decreasing degradation rates.

In the present study we focused on calcification. The incidence of calcification of DSCs upon subcutaneous implantation in rats was evaluated in relation to cytotoxicity, to cellular interactions and to chemical modifications induced by different crosslinking methods.

\section{Materials and methods}

\subsection{Materials}

Dermal Sheep Collagen (DSC), processed from sheep skin $[27,28]$, was obtained from the Zuid Nederlandse Zeemlederfabriek, Oosterhout, The 
Netherlands. Three groups of DSCs were used:

(A) commercially available DSCs;

(B) commercially available DSCs, which had been incubated in tissue culture and thereafter showed a decreased cytotoxicity; and

(C) modified DSCs, i.e. optimized versions of the commercially crosslinked DSCs, and new DSCs crosslinked after first activating carboxylic acid groups within the collagen.

Group $(A)$ Three types of DSC were commercially available. If non-crosslinked, the material is further called NDSC (batch 409-018). Furthermore two types of DSC crosslinked with bifunctional agents were obtained: HDSC (batch 392-001), which was crosslinked with hexamethylenediisocyanate (HMDIC) and GDSC (batch 397-010), which was crosslinked with glutaraldehyde (GA). In short, HDSC was crosslinked for $15 \mathrm{~h}$ at $\mathrm{pH} 7.5$, with a HMDIC-solution of $1.25 \%$ (Desmodur ${ }^{\circledR}$ ) containing $0.3 \%$ of surfactant (Emulvin $\mathrm{W}^{\circledR}$ ), both obtained from Bayer, Wuppertal, Germany. GDSC was crosslinked for $17.5 \mathrm{~h}$ with a $0.5 \%$ GA-solution (Regulan GT $50^{\circledR}$ obtained from BASF, Basel, Switzerland), by slowly raising the $\mathrm{pH}$ from 5 to 7. Discs with a diameter of $8 \mathrm{~mm}$ were punched from HDSC, GDSC and NDSC. The individual weights were approximately $15 \mathrm{mg}$ and all discs were sterilized by gamma irradiation, $2.5 \mathrm{Mrad}$ (Gammaster, Ede, The Netherlands).

Group (B) Sterilized commercially available DSCdiscs were incubated in tissue culture, the so-called methylcelluose (MC)-cell culture (in detail described by van Luyn et al. $[19,21]$, see below: in vitro cytoxicity testing).

HDSC-discs were exposed four times ( $4 \times 6$ days) to MC-cell culture [20], while both GDSC and NDSC were pretreated during two exposure periods (Fig. 1). Thereafter culture-gel remnants were removed by wiping with sterile gauze. These tissue culture (tc)pretreated discs, are further referred to as NDSCtc, GDSCtc or HDSCtc (Fig. 2).

Group $(C)$ To modify DSCs, NDSC was first washed four times with distillcd water, twice with acetonc, and again twice with distilled water. The material was thereafter frozen and lyophilized, followed by four different crosslinking methods.

Modifications of commercial crosslinking methods with bifunctional agents HMDIC and GA resulted in two optimized versions.

Preparation of Tissue Culture (TC) pretreated DSC's

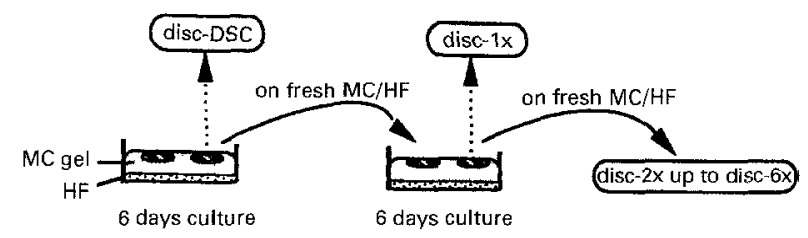

Figure 1 Scheme of the indirect testing of dermal sheep collagen (DSC) with the methylcellulose cell culture and the repeated exposure of DSC discs in order to eliminate cytotoxic products.
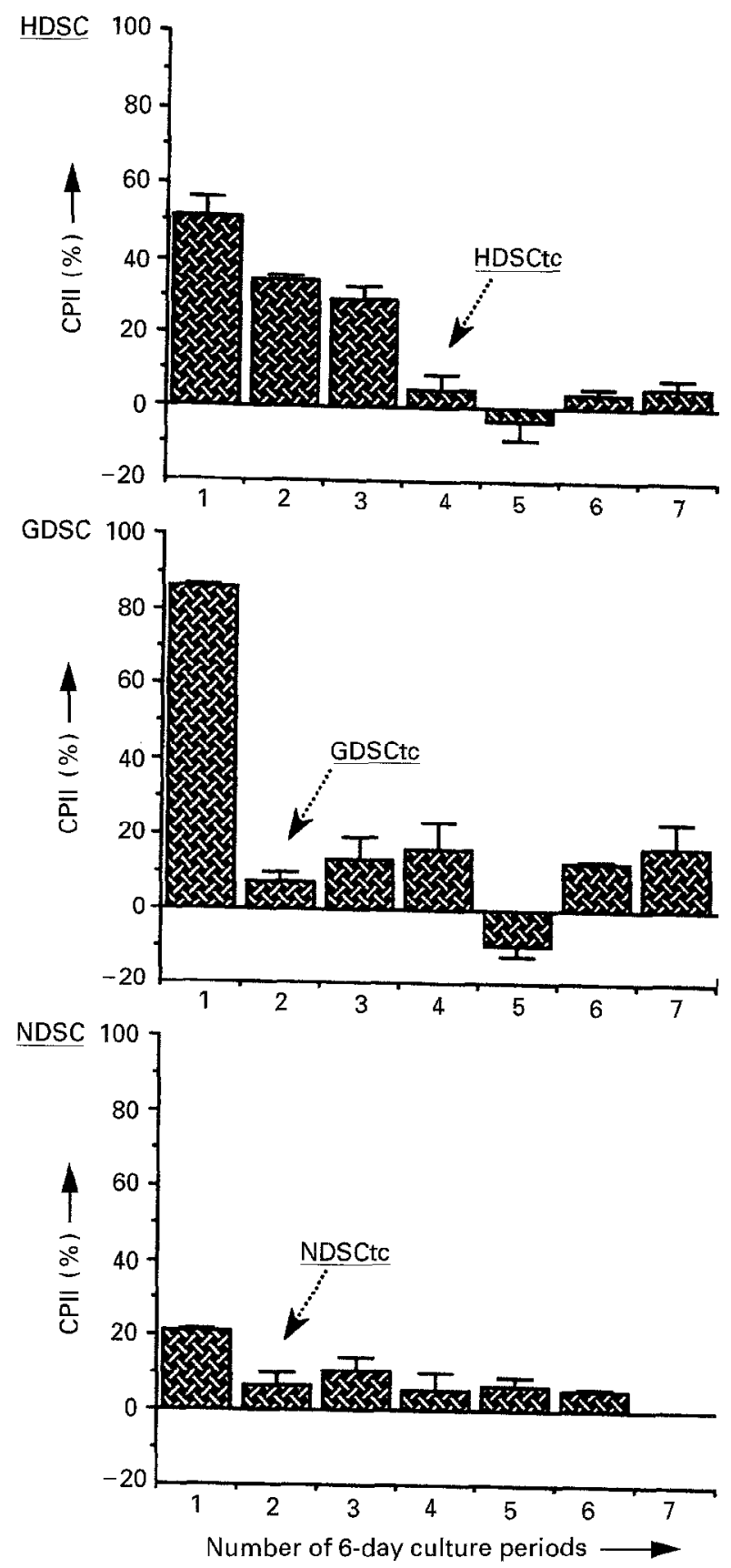

Figure 2 Cell proliferation inhibition indices (CPIIs) of HDSC, GDSC and NDSC after six or seven day culture periods in methylcellulose cell culture. The arrows indicate the samples used for in vivo studies, i.e. discs of HDSCtc after four culture periods and for GDSCtc and NDSCtc after two culture-periods.

For HMDIC-crosslinking [29-31], $1 \mathrm{~g}$ samples were crosslinked in $100 \mathrm{ml}$ phosphate buffer $(0.07 \mathrm{M}$ $\mathrm{NaH}_{2} \mathrm{PO}_{4}, \mathrm{pH} 9.5$ ) containing $1.5 \%(\mathrm{w} / \mathrm{w}) \mathrm{HMDIC}$ (z.S., Merck-Schuchardt, Hohenbrunn, FRG) and $1.0 \%(\mathrm{w} / \mathrm{w})$ Tween 80 (z.S., Merck-Schuchardt, Hohenbrunn, FRG) as a surfactant for $5 \mathrm{~h}$ at room temperature. After crosslinking the samples were rinsed for $30 \mathrm{~min}$ by running tap, washed twice for 30 min with $4 \mathrm{M} \mathrm{NaCl}$ and washed four times for $30 \mathrm{~min}$ with distilled water to remove unreacted HMDIC or surfactant before lyophilization. The resulting DSC is further referred to as HDSC*.

GA-crosslinking $[29,31]$ was performed by immersing $1 \mathrm{~g}$ samples in $100 \mathrm{ml}$ phosphate buffer $(0.054 \mathrm{M}$ $\mathrm{Na}_{2} \mathrm{HPO}_{4}, 0.013 \mathrm{M} \mathrm{NaH} \mathrm{PO}_{4}, \mathrm{pH}$ 7.4) containing 
$0.5 \%(\mathrm{w} / \mathrm{w})$ purified $\mathrm{GA}$ for $1 \mathrm{~h}$ at room temperature. Directly after crosslinking, samples were immersed in a freshly prepared $1.2 \mathrm{mg} / \mathrm{ml}$ solution of $\mathrm{NaBH}_{4}$ (Janssen Chimica, Beerse, Belgium) in phosphate buffer $(\mathrm{pH} \mathrm{7.4)}$ for $1 \mathrm{~h}$ to reduce any unstable compounds. Thereafter, the samples were rinsed for $30 \mathrm{~min}$ by running tap, washed twice for $30 \mathrm{~min}$ with $4 \mathrm{M} \mathrm{NaCl}$ and washed four times for $30 \mathrm{~min}$ with distilled water. The resulting DSC is further referred to as GDSC*.

With the two other methods, acyl azide and carbodiimide crosslinking, tirst carboxylic acid groups were activated and thereafter linked with aminegroups within the collagen $[29,31,33-35]$.

With acyl azide (Aa)-crosslinking [29, 35], the carboxylic acid groups of DSC were first ethylated by treating $1 \mathrm{~g}$ samples for 6 days during constant mixing in $35 \mathrm{ml}$ ethanol (p.a., E. Merck, Darmstadt, FRG) containing $0.2 \mathrm{M} \mathrm{HCl}$. The samples were then washed with a $0.5 \mathrm{M} \mathrm{NaCl}$ solution and the ethyl ester groups were converted to hydrazides by immersing the samples in $100 \mathrm{ml}$ of a $5.0 \%(\mathrm{w} / \mathrm{w})$ solution of hydrazine (monohydrate, 99\%, Janssen Chimica, Geel, Belgium) in $0.5 \mathrm{M} \mathrm{NaCl}$ for $24 \mathrm{~h}$ at room temperature. After hydrazide formation, samples were washed with an ice cold $0.5 \mathrm{M} \mathrm{NaCl}$ solution. Acyl azide formation was performed in $100 \mathrm{ml}$ of a $0.5 \mathrm{M} \mathrm{NaCl}$ solution containing $0.5 \mathrm{M} \mathrm{NaNO}_{2}$ (E. Merck, Darmstadt, FRG) and $0.3 \mathrm{M} \mathrm{HCl}$ at $0{ }^{\circ} \mathrm{C}$ for $10 \mathrm{~min}$. Washing with $0.02 \mathrm{M}$ $\mathrm{Na}_{2} \mathrm{HPO}_{4}$ buffer ( $\mathrm{pH} 8.9$ ) containing $0.5 \mathrm{M} \mathrm{NaCl}$ was the next step, followed finally by the crosslinking by reaction of acyl azide groups with amine groups in $200 \mathrm{ml}$ buffer ( $\mathrm{pH} 8.9$ ) containing $0.5 \mathrm{M} \mathrm{NaCl}$ at room temperature for $48 \mathrm{~h}$. Thereafter, samples were washed twice with $4 \mathrm{M} \mathrm{NaCl}$ and four times with water before lyophilization. Samples are further called AaDSC.

Carbodiimide-crosslinking was performed with EDC ((1-ethyl-3-(3 dimethyl aminopropyl) carbodiimide hydrochloride)) in combination with NHS ((n-hydroxysuccinimide)) to suppress side reactions $[29,33$, 35]. Samples of $1 \mathrm{~g}$ were immersed in $50 \mathrm{ml}$ aqueous solution containing $1.15 \mathrm{~g}(6.0 \mathrm{mmol})$ EDC (MerckSchuchardt, Hohenbrun, FRG) and $0.28 \mathrm{~g}(2.4 \mathrm{mmol})$ NHS (also from Mcrck-Schuchardt) at room tempcrature for $2 \mathrm{~h}$. The $\mathrm{pH}$ of the solution was set at 5.5 by the addition of $\mathrm{HCl}$ and maintained at this value by addition of $0.1 \mathrm{M} \mathrm{NaOH}$ using a $\mathrm{pH}$ stat apparatus (702 SM Titrino, Metrohm, Herisau, Switzerland). After crosslinking samples were washed for $2 \mathrm{~h}$ in a $0.1 \mathrm{M} \mathrm{Na}_{2} \mathrm{HPO}_{4}$ solution to hydrolyze any remaining NHS-activated carboxylic groups and subsequently washed four times with distilled water before lyophilization. This material is further referred to as ENDSC.

The degree of crosslinking of HDSC*, GDSC*, AaDSC and ENDSC was related to the increase in shrinkage temperature $[35,36]$. Shrinkage temperatures $\left(T_{\mathrm{s}}\right)$ of non-sterilized (crosslinked) DSC samples were determined using a shrinkage temperature tester. Test specimens were cut $(5 \mathrm{~mm} \times 5 \mathrm{~mm})$, mounted and immersed in water for at least $30 \mathrm{~min}$. A heating rate of $2.5^{\circ} \mathrm{C} / \mathrm{min}$ was applied and the onset of shrinkage was recorded as the $T_{\mathrm{s}}$.
Discs with a diameter of $8 \mathrm{~mm}$ were punched. The weight was approximately $15 \mathrm{mg}$. All discs of this group were sterilized by ethylene-oxide.

\subsection{In vitro cytotoxicity testing}

DSCs of group B had been exposed several times to tissue culture, i.e. methylcellulose (MC)-cell culture (Fig. 2). DSCs of groups A and C were exposed to tissue culture only once to obtain the degree of cytotoxicity.

Cells to be used in MC-cell culture, i.e. human skin fibroblasts (HF, established cell-line PK 84), were routinely cultured in RPMI 1640 medium (Gibco Biocult Co, Paisley, UK), supplemented with $10 \%$ fetal calf serum (FCS), $2 \mathrm{~mm} / \mathrm{ml}$ glutamine (Glut) (Merck, Darmstadt, FRG), penicillin and streptomycin, both $100 \mathrm{U} / \mathrm{ml}$ (Gibco). After washing twice with phosphate-buffered saline (PBS) (NPBI, Emmer-Compascuum, The Netherlands), HF were harvested from routine culture using $0.25 \%$ trypsin in $\mathrm{Ca}^{++} / \mathrm{Mg}^{++}$. free Hanks' Salt Solution (Gibco).

A stock solution of MC, Methocel high viscosity (3000-4000 cps) from Fluka, Bio Chemica, Buchs, Switzerland, was prepared according to Iscove et al. [37], with Iscove's modification of Dulbecco's medium (IMDM) (ICN Biomedicals Inc., Costa Mesa, CA, USA) in a final concentration of $2.25 \%$.

$\mathrm{MC} / \mathrm{HF}$ mixtures were made by gently and thoroughly mixing $\mathrm{HF} / \mathrm{IMDM}(30 \%)$ with $\mathrm{MC}(50 \%)$ and FCS $(20 \%)$. Pen, Strep and Glut had been added to IMDM in order to obtain the same final concentration in the culture gel as described for RPMI 1640 medium. A final volume of $4.0 \mathrm{ml}$ of culture-gel containing $5 \times 10^{4} \mathrm{HF}$ was placed into each well of 6-well tissue culture plates (Greiner, Alphen a/d Rijn, The Netherlands). Cultures were either used as control cultures or, when discs were placed on the culture gel, as test cultures. All cultures were incubated at $37^{\circ} \mathrm{C}$ in air containing $5 \% \mathrm{CO}_{2}$.

\subsection{Cell counts}

After culturing, discs and gel were removed. The cell layers remaining on the bottom of the wells were extensively washed with PBS in order to completely remove the gel: The cells were trypsinized, resuspended and counted in a Bürker counting chamber. The cell proliferation inhibition index (CPII), expressed as a percentage of cell proliferation in control culture, was calculated as follows:

$$
C P I(\%)=100 \%-\left[\frac{\text { mean cell number of culture with discs }}{\text { mean cell number of control culture }} \times 100 \%\right]
$$

Cell numbers were calculated as the mean of counts \pm s.d. $(n=3)$.

\subsection{Implantations}

Albino Oxford (AO) rats, 3 months of age, were etheranaesthetized and subcutaneous pockets were made 
to the right and left of two midline incisions. DSC discs were implanted in the pockets at a distance of about $1 \mathrm{~cm}$ from the incisions on the back [23, 24].

Implants with surrounding tissue were harvested at 5 or 10 days and in case of groups $\mathrm{A}$ and $\mathrm{C}$ also at 3, 6, 10,15 and, if not degenerated, at 20 and 30 weeks $(n=3)$.

\subsection{Microscopy}

Implants were fixed in $2 \%(\mathrm{v} / \mathrm{v}) \mathrm{GA}$ in $0.1 \mathrm{~mol}$ PBS. Specimens were cut into small blocks $\left(2 \mathrm{~mm}^{3}\right)$ after at least $24 \mathrm{~h}$ of fixation at $4^{\circ} \mathrm{C}$.

Blocks were postfixed in $1 \% \quad \mathrm{OsO}_{4}, \quad 1.5 \%$ $\mathrm{K}_{4} \mathrm{Fe}(\mathrm{CN})_{6}$ in PBS [38], dehydrated in graded alcohols and embedded in Epon 812. Semithin sections $(1 \mu \mathrm{m})$ were made of several levels of each block and stained with toluidine blue. Light microscopical evaluations were performed double blind concerning cellular events and calcification.

Ultrathin sections of the same levels were cut and stained with uranyl acetate and lead citrate and examined with a Philips EM 201 transmission electron microscope, operated at $40 \mathrm{kV}$.

\section{Results}

\subsection{Initial properties}

NDSC, the non-crosslinked version of processed dermal sheep collagen, had a shrinkage temperature $\left(T_{\mathrm{s}}\right)$ of $56.0 \pm 0.3^{\circ} \mathrm{C}$. The modified DSCs of group C had increased $T_{\mathrm{s}}$ values, indicating that crosslinking had occurred [29-35]. The HMDIC-crosslinked HDSC* had the lowest $T_{\mathrm{s}}$ of $73.8 \pm 0.3^{\circ} \mathrm{C}$, while the GAcrosslinked GDSC* had a $T_{\mathrm{s}}$ of $77.7 \pm 0.3^{\circ} \mathrm{C}$. The acyl-azide-crosslinked AaDSC and the EDC/NHScrosslinked ENDSC had a $T_{\mathrm{s}}$ of, respectively, $82.4 \pm 0.4$ and $86.6 \pm 0.4^{\circ} \mathrm{C}$.

NDSC had a fibrous structure, whitish colour and supple hand. All other DSCs had the same fibrous structure. HDSC, HDSC*, AaDSC and ENDSC all had the same whitish colour. In contrast both GDSC and GDSC* $^{*}$ had a more yellowish colour. ENDSC was the only DSC with some decrease in suppleness as well as wettability.

\subsection{Cytotoxicity (Table I)}

The commercially available DSCs of group A were one-time-exposed to $\mathrm{HF}$ in MC cell culture. NDSC induced an inhibition of cell proliferation of $20 \%$, as measured after 6 days of exposure to human fibroblasts (HF). The morphology of the HF was normal as compared to the control culture.

Cultures with discs of HDSC showed an inhibition of cell proliferation of $50 \%$ with moderate lipid degeneration of $\mathrm{HF}$ at the edge of the cell-free zone. Commercially available GDSC induced a very high level of cytotoxicity with $85 \%$ cell growth inhibition, large cell-free zones and lipid-degenerative effects.

Further exposure to tissue culture (group B) was found to remove or considerably decrease in vitro cytotoxic effects (see also Fig. 2.) After being exposed
TABLE I Cytotoxicity of DSCs, expressed as the cell proliferation inhibition indices (CPII's), after 7 days of cell culture

\begin{tabular}{lcl}
\hline & $\begin{array}{l}\text { Cytotoxicity } \\
\text { (CPII, \%) }\end{array}$ & Morphology \\
\hline NDSC & $20.8 \pm 1.0$ & normal \\
HDSC & $51.5 \pm 5.3$ & moderate lipid degeneration \\
GDSC & $86.9 \pm 0.6$ & high lipid degeneration \\
NDSCtc & $6.4 \pm 1.6$ & normal \\
HDSCtc & $3.8 \pm 1.4$ & normal \\
GDSCtc & $7.9 \pm 1.9$ & low lipid degeneration \\
HDSC* & $13.4 \pm 10.4$ & normal \\
GDSC* & $15.8 \pm 10.2$ & low lipid degeneration \\
ENDSC & $-4.5 \pm 3.4$ & normal \\
AaDSC & $-2.2 \pm 4.9$ & normal \\
\hline
\end{tabular}

for $2 \times 6$ days to $\mathrm{HF}$ in MC cell culture NDSCtc did no longer induce cell growth inhibition (and of course cell morphology was normal). HDSCtc needed to be exposed for $4 \times 6$ days in order to show no significant inhibition of cell proliferation and normal morphology.

A $10 \%$ cell growth inhibition was found for GDSCtc when exposed for $2 \times 6$ days; further exposure periods (performed up to seven times) did not further decrease this number [21].

Of the modified DSCs of group C, one-time-exposure to $\mathrm{HF}$ in $\mathrm{MC}$ cell culture resulted in a $13 \%$ inhibition of cell proliferation for HDSC*, without deviant morphology. The modified GDSC* induced a low cell growth inhibition of $16 \%$ with low lipid degeneration of cells at the edge of the very small cell-free zone.

AaDSC and ENDSC neither induced inhibition of cell proliferation nor deviances in cell morphology as compared to the control culture.

\subsection{Cellular infiltration of DSCs (Table II)}

DSCs with cell growth inhibition percentages as detailed above were implanted.

In general, neutrophils and macrophages were the very first cell types to arrive at the site of wounding and insertion of the foreign body. In the second instance, already observed from day 5 on but most prominently at day 10 and later time points, fibroblasts were present, while giant cells were being formed. The reaction of neutrophils and macrophages from day 10 on usually decreased.

A cell type not normally present during the reaction to biomaterials, i.e. the basophil-like cell [23, 24], was locally found in all DSCs from day 5 on. These cells seemed specifically attracted by crystals sometimes present in all DSCs, but mostly so in GDSC. Furthermore, some lymphocytes were observed in all DSCs from week 6 on. Details concerning the different DSCs are described below.

Concerning materials of group A: with NDSC only few neutrophils were present at the edges, while macrophages were hardly observed. Also at later time points, e.g. from day $10 \mathrm{on}$, hardly any neutrophils or macrophages were found in NDSC. Similarly, fibroblast ingrowth and giant cell formation was hardly or 
TABLE II Cellular infiltration and morphology of implanted DSCs

\begin{tabular}{|c|c|c|c|c|}
\hline & $\begin{array}{l}\text { Days } 5 \text { and } 10 \\
\text { Infiltration }\end{array}$ & Remarks & $\begin{array}{l}\text { Week } 3 \text { to } 15 \text { or } 30 \\
\text { Infiltration } \\
\text { giants/fibro's }\end{array}$ & Remarks \\
\hline NDSC & hardly & no & hardly & $\begin{array}{l}\text { no rat-collagen } \\
\text { degen. week } 6\end{array}$ \\
\hline HDSC & moderate & deviant neutro's & high & degen. week 15 \\
\hline GDSC & high & $\begin{array}{l}\text { lipid accumulation } \\
\text { many cell debris }\end{array}$ & high & degen. week 15 \\
\hline NDSCtc & hardly & no & $\mathrm{ND}$ & \\
\hline HDSCtc & slight & no & ND & \\
\hline GDSCtc & slight & $\begin{array}{l}\text { neutrophils/glycogen } \\
\text { accumulation }\end{array}$ & ND & \\
\hline HDSC* & slight & normal & high & degen. week 15 \\
\hline GDSC $^{*}$ & slight/moderate & $\begin{array}{l}\text { low lipid } \\
\text { accumulation }\end{array}$ & hardly & $\begin{array}{l}\text { degen. week } 15 \\
\text { less rat-collagen }\end{array}$ \\
\hline ENDSC & slight & no & moderate/high & $\begin{array}{l}\text { new collagen matrix } \\
\text { degen. }>\text { weck } 30\end{array}$ \\
\hline AaDSC & slight/moderate & $\begin{array}{l}\text { mainly macrophages } \\
\text { with lipid accumulation }\end{array}$ & moderate/high & $\begin{array}{l}\text { new collagen matrix } \\
\text { degen. }>\text { week } 30\end{array}$ \\
\hline
\end{tabular}

not observed. NDSC had degenerated within 6 weeks. Moderate infiltration of neutrophils and macrophages was observed with HDSC. The neutrophils locally had deviant morphologies with disintegration of the cytoplasm. In the second instance a high infiltration of fibroblasts and giant cells was observed. The fibroblasts thereby produced new collagen, while giant cells degraded the material within 15 weeks by surrounding and enclosing parts of collagen bundles.

In contrast, high cell numbers at first infiltrated GDSC; many cells, probably mostly neutrophils, had died leaving a lot of cell debris and lipid. Similarly to HDSC, fibroblast and giant ccll infiltration occurred, followed by degradation at week 15 .

The tissue culture pretreated matcrials of group $B$ were only observed at days 5 to 10 . NDSCtc induced a tissue reaction which was similar to that of NDSC, i.e. hardly any cell infiltration occurred. Slightly more, although still not very many, neutrophils and macrophages infiltrated HDSCtc. These cells had normal morphologies. Neutrophil infiltration in GDSCtc was increased, while cells were strongly activated and had high concentrations of glycogen. Fibroblasts and giant cells infiltrated HDSCtc but not NDSCtc and GDSCtc.

Concerning group $\mathrm{C}$; few neutrophils were found to infiltrate HDSC*, AaDSC and ENDSC. Only in case of GDSC* an increase of neutrophils with disintegrated cytoplasm was observed. Macrophages infiltrated these materials in normal numbers, with the exception of AaDSC. The increased numbers of macrophages in the latter material contained many lipid droplets. From week 3 on a moderate/high infiltration of fibroblasts and giant cells was observed with HDSC*, AaDSC and ENDSC. The giant cells thereby degraded HDSC* within 15 weeks. In the case of AaDSC and ENDSC, at 20 and 30 weeks a matrix of collagen bundles, probably of rat origin, was obtained. GDSC* hardly induced fibroblast infiltration, while giant cells were also hardly present. As a consequence little new formation of rat collagen was observed and the material had degenerated within 15 weeks.
TABLE III Calcification of implanted DSCs

\begin{tabular}{|c|c|c|c|c|c|c|c|c|}
\hline & \multicolumn{8}{|c|}{ Implantation period } \\
\hline & $5 \mathrm{~d}$ & $10 \mathrm{~d}$ & 3 wk & $6 \mathrm{wk}$ & $10 \mathrm{wk}$ & $15 \mathrm{wk}$ & $20 \mathrm{wk}$ & $30 \mathrm{wk}$ \\
\hline NDSC & - & - & - & - & & & & \\
\hline HDSC & - & ++ & ++ & - & - & & & \\
\hline GDSC & - & - & - & - & - & & & \\
\hline NDSCtc & - & - & & & & & & \\
\hline HDSCtc & - & - & & & & & & \\
\hline GDSCtc & + & + & & & & & & \\
\hline HDSC* & - & - & - & - & - & - & & \\
\hline $\mathrm{GSC}^{*}$ & - & ++ & +++ & +++ & +++ & + & & \\
\hline ENDSC & - & - & - & ++ & - & - & - & - \\
\hline AaDSC & - & - & + & - & - & - & - & - \\
\hline
\end{tabular}

\subsection{Calcification during implantation (Table III)}

By LM, the occurrence of calcification could be registered by red spot-like or complete staining of the otherwise blue-stained collagen bundlcs.

By TEM, the slightest incidence of calcification could be observed as deposits of (small) ncedlc-likc crystals or as large black areas which all contained calcium and phosphorus (as previously detected with $\mathrm{X}$-ray micro-analyis [23]).

Within group A, HDSC showed calcifications in the 10-day-to-3-week specimens. These were locally in the extracellular collagen bundles found in large deposits (Fig. 3). In contrast, with GDSC (Fig. 4) and NDSC no calcific deposits were found.

The tissue-culture-pretreated DSCs of group B, only investigated at days 5 and 10 after implantation, showed calcifications with GDSCtc but not with NDSCtc and HDSCtc. The calcifications in GDSCtc were present as many small spots at both the edges of the collagen bundles as well as distributed over the collagen bundles (Fig. 5). The collagenous parts of GDSCtc as well as NDSCtc in general showed a more "degenerated" morphology (i.e. loss of fibrillar structure, and sometimes a transition to a more gelatinous structure). In contrast, collagen bundles of HDSCtc, 


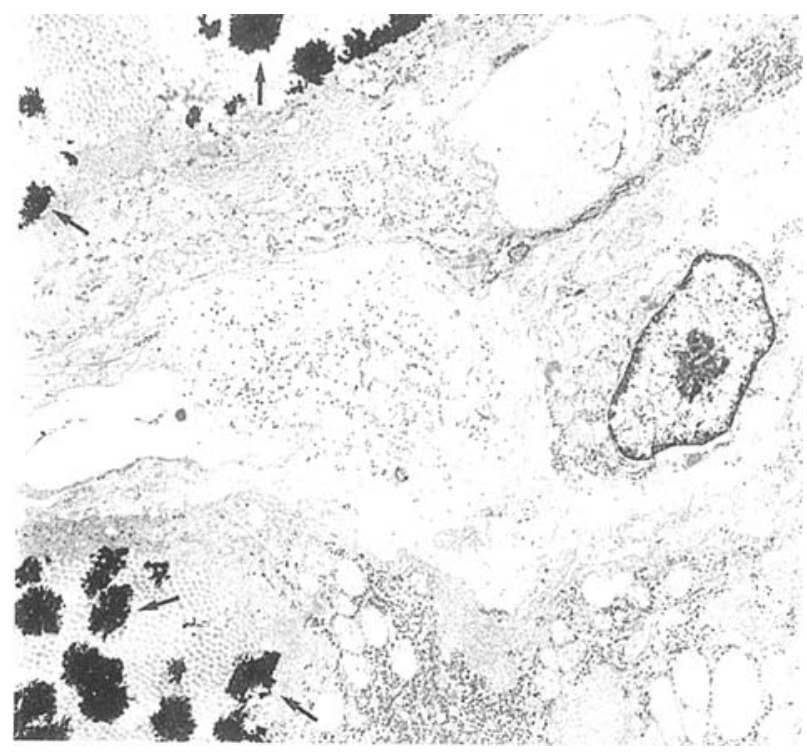

Figure 3 Electron-dense deposits of calcium phosphate (arrows) in the collagen bundles and high infiltration of cells present in HDSC 14 days after implantation. Magnification $7142 \mathrm{x}$.

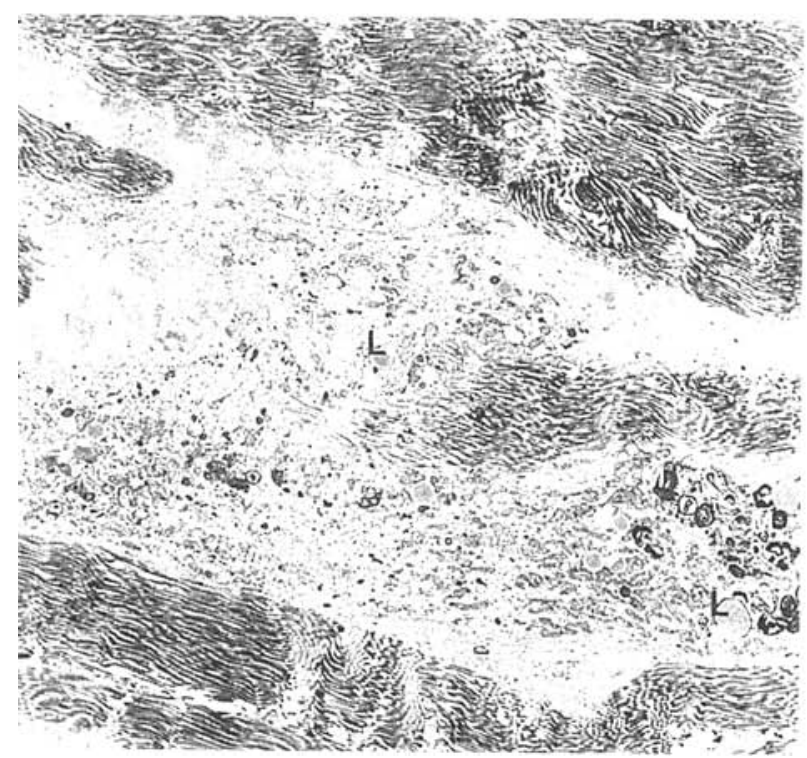

Figure 4 High presence of cell debris including lipid droplets (L) and myelin structures (M) in between the collagen bundles of GDSC 10 days after implantation. Note: no calcification was observed in the bundles of GDSC. Magnification 4685x.

although having been exposed to tissue culture twice as much, did not show a degencrated morphology.

The modified materials of group $C$ showed one example with a high degree of calcification. GDSC* contained small deposits of calcifications, regularly distributed in all collagen bundles, in the 10-day specimen (Fig. 6). Calcification increased and from week 3 (Fig. 7) up to week 10 very large deposits were observed, which finally made it very difficult to recognize and retrieve the original matrix structure of GDSC* (Fig. 8a, b). Thereafter the calcific deposits seemed to disappear via some extracellular pathway. Thus, at week 15, only many small calcific deposits

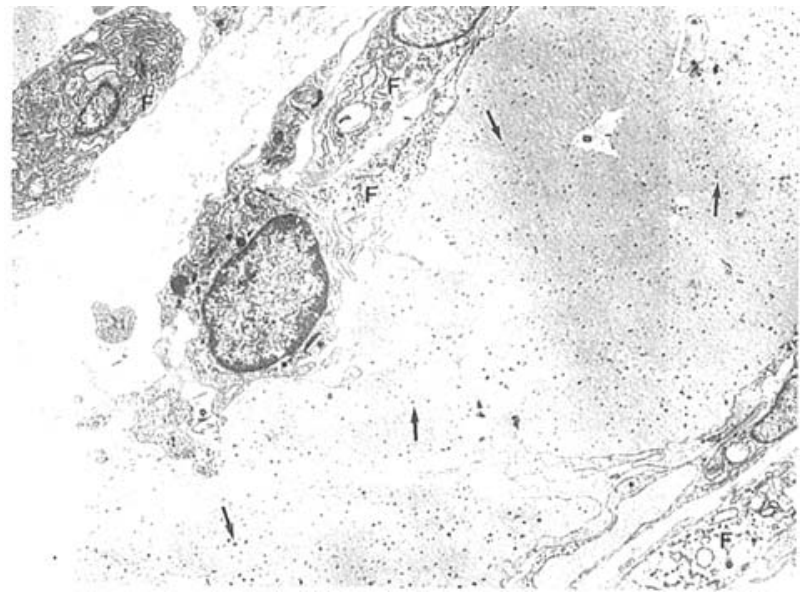

Figure 5 Very small deposits of calcium phosphate (arrows) in the collagen bundles of GDSCtc 10 days after implantation. Furthermore the low cellular ingrowth, of mainly fibroblasts $(F)$, is shown. Magnification 7142x.

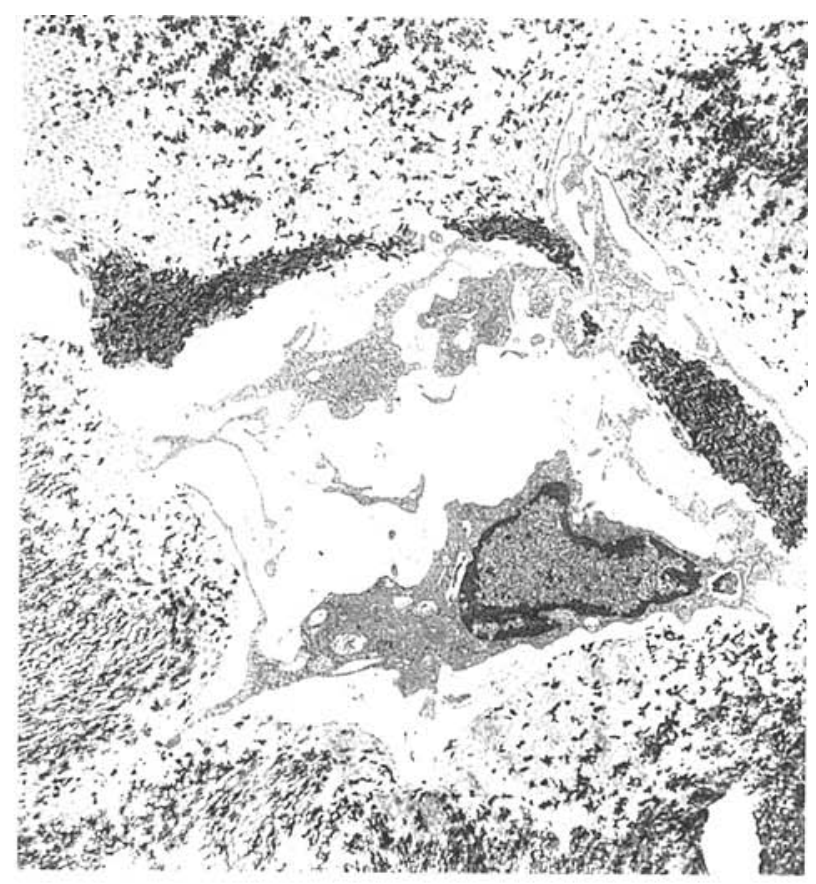

Figure 6 High percentage of calcium phosphate present in the collagen bundles of GDSC* and low ingrowth of cells after 10 days of implantation. Magnification 4685x.

were observed, but the original matrix structure of

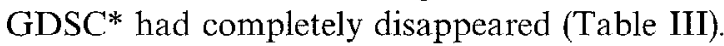

AaDSC and ENDSC only induced a little calcification in the collagen bundles of the 3-and 6-week implants, respectively (Figs 9 and 10). A collagen matrix, probably of rat origin, was still well retrieved after 20 and 30 weeks of implantation with AaDSC and ENDSC.

With HDSC* at no time were deposits of calcification found.

\section{Discussion}

The aim of this study was to investigate the incidence of calcification of different (crosslinked) dermal sheep 


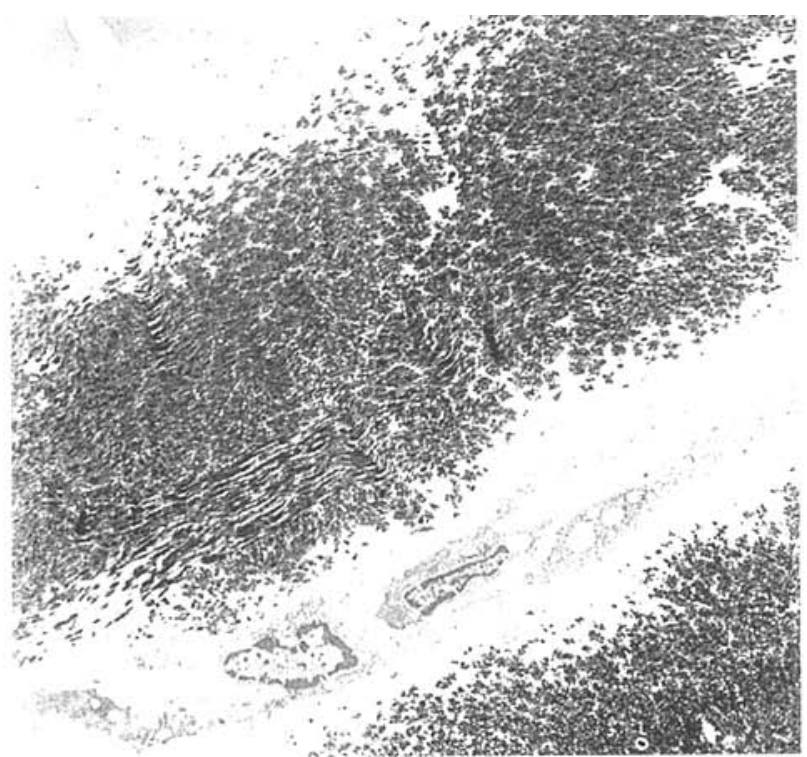

Figure 7 Ongoing calcification of the collagen bundles of GDSC* 3 weeks after implantation, with again ongoing very low cellular ingrowth. Magnification 4685x.
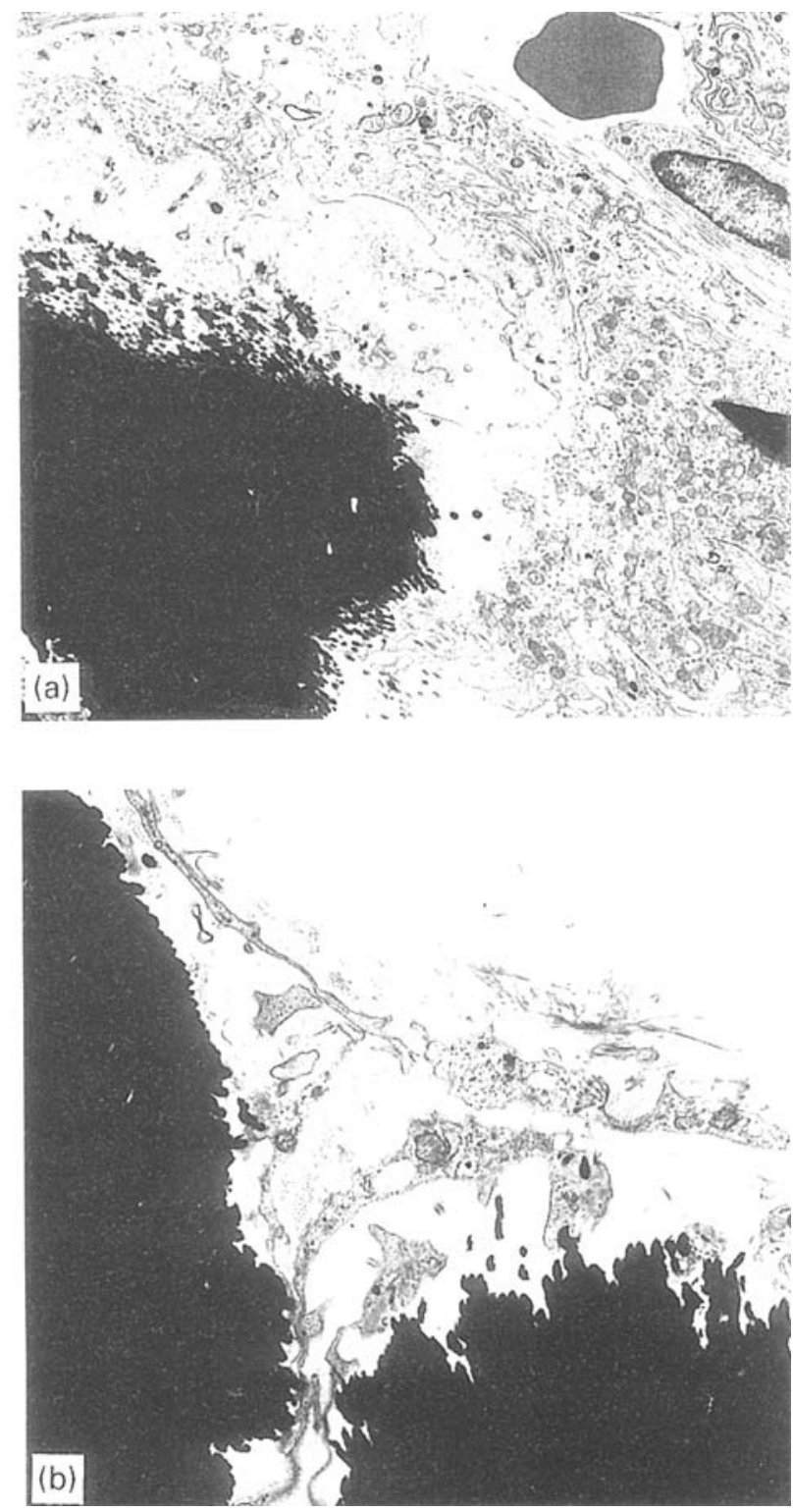

Figure 8 Huge calcified collagen bundles of GDSC* 10 weeks after implantation. Magnification (a) $7142 \mathrm{x}$ and (b) 10752x.

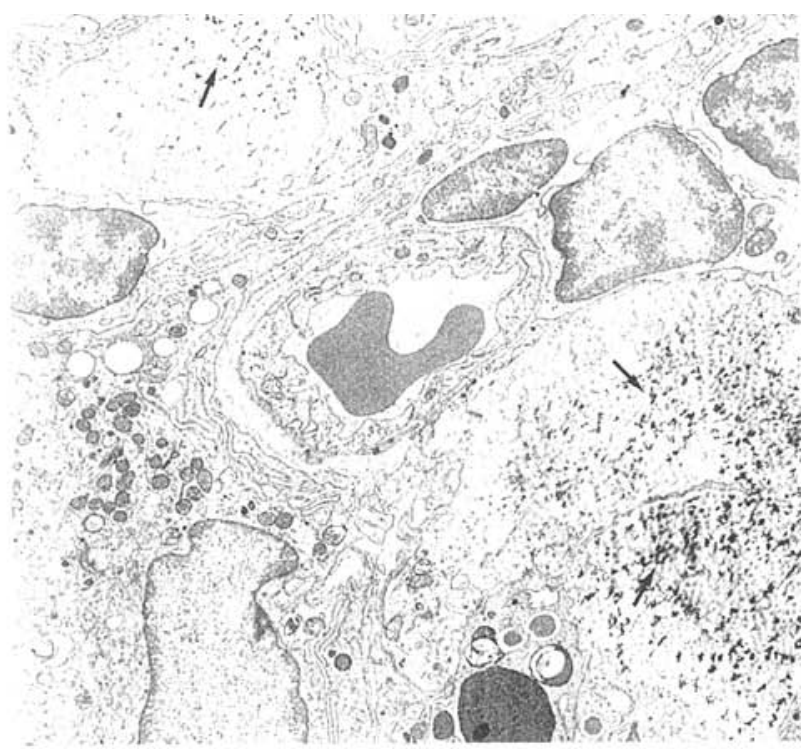

Figure 9 Slight calcification within the collagen bundles of AaDSC (arrows), which was only observed 3 weeks after implantation. Magnification 4500x.

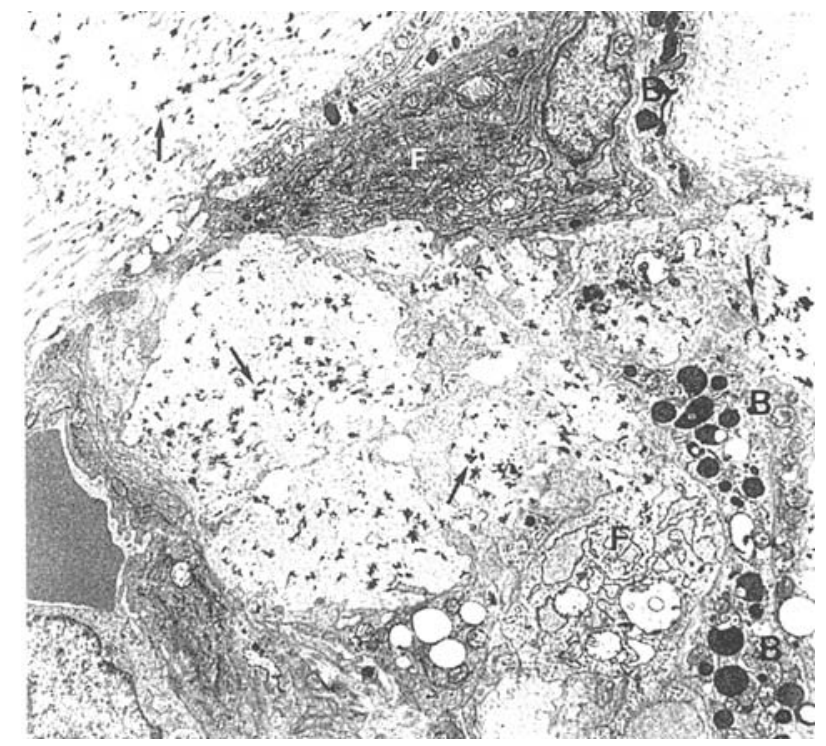

Figure 10 Small spots of calcium phosphate (arrows) in the collagen bundles of ENDSC, only observed in the 6-weeks implant. Furthermore fibroblasts (F) and a basophil-like cell (B) are present. Magnification 7142x.

collagens (DSCs) with respect to their specific properties, during subcutaneous implantation in rats.

\subsection{Relation between calcification and cytotoxicity}

Cytotoxic products can influence subjection to calcification of crosslinked collagen.

Results of Table I show that HDSC (with 50\% cytotoxicity) induced calcification, while the same material, after removal of its cytotoxic products (see, HDSCtc and HDSC** Table II) does not. Release of cytotoxic products will influence the tissue environment and thereby, as observed, change subjection to calcification of the material. 
With GDSCs also although giving a result opposite to HDSC, a relation between calcification and cytotoxicity was found. The severely cytotoxic GDSC $85 \%$ ) did not calcify, while the pretreated, very low cytotoxic GDSCtc already induced slight calcification 5 days after implantation and the low cytotoxic GDSC* provoked severe calcification from 10 days on (Table III).

As previously discussed [21, 31], high levels of residual glutaraldehyde must be responsible for the severe cytotoxicity of GDSC. These residuals are not present in the case of GDSCtc and GDSC* and will therefore after implantation, result in a different tissue environment in comparison to GDSC, resulting in absence of calcification. However, with respect to the biocompatibility of GDSC it is not acceptable to recommend this material as a non-calcifying material.

These results show that the presence (moderate to severe levels) or absence of cytotoxic products can both define incidence of calcification of a crosslinked material.

\subsection{Relation between calcification and cellular infiltration}

After implantation of DSCs, no relation was found between calcification and cellular infiltration.

First, with NDSC and NDSCtc cellular infiltration hardly occurred and calcification was not induced. However GDSCs with low cellular infiltration (see GDSCtc and GDSC*, Table I) did calcify, but in contrast to these, other crosslinked materials with low cellular infiltration (see HDSCtc and HDSC* Table I) did not. These results imply that there is no relation between (very) low cellular infiltration and calcification.

With respect to moderate or high cellular infiltration, which was observed with HDSC and GDSC, respectively, only HDSC was subjected to calcification (Tables II and III).

Also after use of other crosslinking methods (activation of carboxylic groups), i.e. ENDSC, and AaDSC, no relation between calcification and cellular infiltration could be made. ENDSC, showed 'delayed' infiltration of cells, and although the material was completely infiltrated after 3 weeks, calcification was only observed after 6 weeks of implantation. With AaDSC an inflammatory reaction, i.e. influx of monocytes [26], was observed from day 5 on, but only slight calcification was observed after 3 weeks of implantation.

With respect to the cellular infiltration, Schoen et al. [13] hypothesized that the potentiation of cellular damage at or near the material might have a promoting role in calcification. This hypothesis is in contrast with results of Grabenwöger et al. [14] and our findings with GDSC [24]. With the latter a lot of cell damage/debris was observed (Fig. 4), but no calcification was found up to 15 weeks after implantation. However, it might well be that the pathophysiologic environment (i.e. leaching of high levels of GA [21, 31]) overrules possible calcification as a consequence of cell damage/debris.

\subsection{Possible cause of calcification of the differently crosslinked DSCs}

NDSCs did not calcify and as discussed above calcification is not related to cellular infiltration. As a consequence, calcification of non-cytotoxic crosslinked DSCs must be due to the crosslinks induced.

Modified GA crosslinking, i.e. highly crosslinked GDSC*, was found to induce severe amounts of calcification (Table III). With GDSC*, in contrast to commercially available GDSC, $\mathrm{NaBH}_{4}$ was used to reduce any unstable compounds present after crosslinking [32]. As a result cyclic bonds may be present among these stable crosslinks (e.g. pyridinium bonds) [31], and these might well function as a nucleation point for calcification. Previously, Levy et al. [39] also discussed the presence of pyridinium crosslinks in GAcrosslinked collagen in relation to calcification, because compounds similar to pyridinium were found in bone-derived collagen. Furthermore, Nimni et al. [40] suggestcd that a (di)pyridine structure, accounting for the high stability of the crosslinks, may be involved in calcification of GA-crosslinked collagens. This hypothesis is confirmed in the present study from the results with GDSC* (see explanation above), GDSCtc, and HDSC*. In GDSCtc, because no reduction agent was used, many unstable crosslinks and probably less stable cyclic crosslinks will be present $[21,24,32]$. The latter might be an explanation for very slight calcification of GDSCtc, mainly observed at the edges of the collagen bundles, in comparison with GDSC*.

In contrast, optimal crosslinking of DSC with HMDIC $\left(\operatorname{HDSC}^{*}\right)$ will neither result in unstable nor in cyclic crosslinks [21]. HDSC* did not calcify at all, which forms further evidence for possible involvement of cyclic crosslinks in the process of calcification.

Furthermore, prevention of calcification was suggested by performing alternative crosslinkings, e.g. by activation of the carboxylic acid groups [16-18]. Bernacca et al. $[16]$ and others $[17,18]$ suggested that carboxyl residues should be involved and blockage of these groups, e.g. by crosslinking with acyl azide activation or by epoxy compounds pretreatment, should be effective in reducing calcification. Also from our study it is obvious, that alternative crosslinking methods (see ENDSC and AaDSC), in comparison to crosslinking with GA, clearly reduced calcification of the collagen. However, in our opinion this is not due to blockage of the carboxylic residues, because crosslinking with HMDIC, which only links via amino groups, did not induce calcification of the collagen. Furthermore, all DSCs of this group were sterilized by ethylene oxide which will block the remaining $\mathrm{NH}_{2}$ groups of each type of DSC. This also proves that neither $\mathrm{NH}_{2}$, nor $\mathrm{COOH}^{-}$groups are involved in calcification.

In summary we can conclude, that there is a strong relation between calcification and degree of cytoxicity. Furthermore, it is obvious that calcification is not related to cellular ingrowth but to the finally obtained crosslinked material, and possibly due to the presence of stable (cyclic) crosslinks in the collagen.

From this fundamental study, it is clear that HDSC*, ENDSC and $\Lambda \mathrm{aDSC}$ are promising products 
for several application sites. As discussed by Schoen et al. [14], the subcutaneous model proved to be a good model for studying calcification, despite the absence of dynamic mechanical stress which also may promote calcification $[6,41]$. Crosslinking of bioprosthetic heart valves by, for example, HMDIC can be very promising for the future. Finally, GDSC*, which induced severe calcification, could be a promising inducer of bone formation.

\section{Acknowledgement}

The authors wish to thank Mr P. Van der Sijde and Mr D. Huizinga for the photography.

\section{References}

1. B. STRATES, J. LAIN and M. E. NIMNI, "Collagen, Vol III, Biotechnology", edited by M. E. Nimni (CCR Press, Boca Raton, Fl, 1988) pp. 273-292.

2. V. J. FERRANS, S. L. HILBERT, Y, TOMITA, M. JONES and W. C. ROBERTS, ibid. pp. 145-188.

3. M. VALENTE, U. BOR'TOLOTII and G. THIENE, Amer. J. Pathol. 119 (1985) 12

4. H. HARASAKI, R. I. KIRAI.Y, G. B. JACOBS, J. L. SNOW and Y. NOSE, J. Thorac. Cardiovasc, Surg. 79 (1980) 125.

5. R. J. LEVY, F. J. SCHOEN, R. S. SHERMAN, J. NICHOLS, M. A. HAWLEY and S. A. LUND, Amer. J. Pathol. 122, (1986) 71.

6. F. J. SCHOEN, Trans. Amer. Soc. Artif. Intern. Organs, 3 (1987) 8 .

7. G. GOLOMB, F. J. SCHOEN, M. S. SMITH, J. LINDEN, M. DIXON and R. J. LEVY, Amer. J. Pathol. 127 (1987) 122.

8. G, GOLOMB, I. LEWINSTEIN, V. EZRA and F. J, SHOEN, Biomaterials 13 (1992) 353.

9. G. GOLOMB and V. EZRA, J. Biomed. Mater. Res. 25 (1991) 25.

10. G. GOLOMB, M. DIXON, M. S. SMITH and F. J. SCHOEN, J. Pharm. Sci. 76 (1987) 271.

11. G. GOLOMB, A. SCHLOSSMAN, H. SAADEH, M. LEVI, J. M. VAN GELDER and E. BREUER, Pharm. Res. 9 (1992) 143.

12. C. L. WEBB, F. J. SCHOEN and R. J. LEVY, Exp. Mol. Path. $50(1989) 291$

13. F. J. SCHOEN, H. HARASAKI, K. M. KIM, H. C. ANDERSON and R. J. LEVY, J. Biomed. Mater. Res. Appl. Biomater. 22 A1 (1988) 11.

14. M. GRABENWÖGER, M. GRIMM, E. EYBL, C. LEUKAUF and M. M. MÜLLER, J. Biomed. Mater. Res. 26 (1992) 1231.

15. X. TINGFEI, M. JIAZHEN, T. WENHUA, L. XUEHUI, L. SIIUIIUI and X. BAOSIIU, ibid. 36 (1992) 1241.

16. G. M. BERNACCA, W. R. DIMITRI, A. C. FISHER, T. G. MACKAY and D. J. WHEATLEY, Biomaterials 13 (1992) 345.
17. C. A. PEREIRA, M. LEE and S. A. HABERER, J. Biomed. Mater. Res. 24 (1990) 345.

18. H. PETITE, I. RAULT, A. HUC, P. H. MENASCHE and D. HERBAGE, ibid. 24, (1990) 179

19. M. J. A. VAN LUYN, P. B. VAN WACHEM, L. H. H. OLDE DAMINK, J. TEN HOPPER, J. FEIJEN and P. NiEUWENHUiS, J. Mater. Sci. Mater. Med. 2 (1991) 142.

20. M. J. A VAN LUYN, P, B. VAN WACHEM, L. H. H. OLDE DAMINK, J. FEIJEN and P. NIEUWENHUIS, Symposium Proceedings "Tissue Inducing Biomaterials", 252 (1992) 167.

21. idem. J. Biomed. Mater. Res. 26 (1992) 1091.

22. idem. Biomaterials 13 (1992) 1017.

23. P. B. VAN WACHEM, M. J. A. VAN LUYN, H, K. KOERIEN, L. H. H. OLDE DAMINK, H. TEN HOOPEN, J. FEIJEN and P. NIEUWENHUIS, ibid 12 (1991) 215.

24. idem., Cell and Materials 1 (1991) 251.

25. P. B. VAN WACHEM, M. J. A. VAN LUYN, L. H. H. OLDE DAMINK, P. J. DIJKSTRA, J. FEIJEN and P. NIEUWENHUIS, Symposium Proceedings "Tissue Inducing Biomaterials", 252 (1992) 117.

26. idem., J. Biomed. Mater. Res. 28 (1994) 353.

27. T. M. VAN GULIK, Neth. J. Surg. 39 (1987) 90.

28. T. M. VAN GULIK, R. A. CHRISTIANO, A. H. BROEKHUIZEN, E. L. F. B. RAAYMAKERS and P. J. KLOPPER, ibid. 41 (1989) 65.

29. L. H. H. OLDE DAMINK, P. J. DIJKSTRA, M. J. A. VAN LUYN, P. B. VAN WACHEM, P. NIEUWENHUIS and J. FEIJEN, Abstract, Fourth World Biomaterials Congress, Berlin, FRG, April 24-28 (1992) p. 45.

30. idem., J. Mater. Sci. Mater. in Med. (in press).

31. L. H. H. ULDE UAMINK, Thesis; University of Twente, The Netherlands, 1993. Ch. 9.

32. I. H. H. OT.DE DAMINK, P. J. DIJKSTRA, M. J. A. VAN LUYN, P. B. VAN WACHEM, P. NIEUWENHUIS and J. FEIJEN, J. Mater. Sci. Mater. Med. (in press).

33. idem., Biomaterials (submitted)

34. L, H. H. OLDE DAMINK, H. TEN HOOPEN, P. J. DIJKSTRA, M. I. A. VAN LUYN, P. B. VAN WACHEM, P. NIEUWENHUIS and J. FEIJEN, J. Biomed. Mater. Res. 29 (1995) 139

35. L. H. H. OLDE DAMINK, Thesis, University of Twente, The Netherlands, 1993. Ch. 8.

36. P. J. FLORY and R. R. GARRETT, J. Arner. Chem. Soc. 80 (1958) 4836

37. N. N. ISCOVE and H. SCHREIER, Immunological Methods (Academic Press, 1979).

38. E. H. BLAAUW, J. A. OOSTERBAAN and J. M. SCHAKENRAAD, Biomaterials 10 (1989) 356.

39. R. J. LEVY, F. J. SCHOEN, J. T. LEVY, A. C. NELSON, S. I. HOWA R D and I. J. OSHRY, Amer. J. Path 113(1983) 143.

40. M. E. NIMNI, D. CHEUNG, B. STRATES, M. KODAMA and K. SHEIKH, J. Biomed. Mater. Res. 21 (1987) 741.

41. M. J. THUBRIKAR, J. D. DECK, J. AOAUD and P. NOLAN, J. Thorac. Cardiovasc. Surg. 86 (1983) 115.

Received 12 January

and accepted 3 July 1994 